\title{
Influence of environmental variables on the growth of Leuciscus cephalus (Linnaeus 1766), in the River Durance, South-east France
}

\author{
P. Bouchard ${ }^{1}$ \\ R. Chappaz ${ }^{1}$ \\ L. Cavalli ${ }^{1}$ \\ G. Brun ${ }^{1}$
}

Keywords : growth, regulated river, Leuciscus cephalus, mesologic parameters.

The chub, Leuciscus cephalus, colonizes the Durance river from its confluence with the Rhône river (alt. $13 \mathrm{~m}$ ) up to the Serre Ponçon dam (alt. $780 \mathrm{~m}$.). The Durance has been exposed to strong human pressure, notably dam construction, reduction of flow rate and perturbation of the natural zonation patterns. The linear growth of chub was studied by scale measurement at six stations in the Durance catchment area : two of which are located in its main tributaries, the Buech river and the Verdon. An analysis (ANOVA) of the mean size of fish from one to five years of age shows significant differences between the stations. Principal Component Analysis, in which the stations are characterized by eight mesological variables associated with the density of invertebrates and the number of degree-days above $12^{\circ}$ and $22^{\circ} \mathrm{C}$ established a correlation between chub growth and species habitat, defined in terms of current flow rate, depth and substrate type and temperature. This correlation could be explained in two ways : 1 - in slow-flowing homogenous riffle zone, the low water depth and absence of shelters limit the diversity of habitats and the biological richness; nevertheless the abundance of invertebrates does not seem to play an important role ; 2 - in zone of slow flowing riffles subjected to large daily and seasonal variations in water temperature, as in this mediterranean river, temperature might be quite high. Fish older than two years, therefore prefer zones of deep water, where the thermic inertia is stronger.

Influences des variables de l'environnement sur la croissance de Leuciscus cephalus (Linné 1766), dans la Durance, rivière du sud-est de la France

Mots clés : croissance, rivière regulée, Leuciscus cephalus, paramètres mésologiques.

Le chevaine, Leuciscus cephalus, colonise la Durance depuis sa confluence avec le Rhône (alt. $13 \mathrm{~m}$ ) jusqu'au barrage de Serre Ponçon (alt. $780 \mathrm{~m}$.). Cette rivière a subi une forte pression anthropique qui se traduit, en particulier, par la construction de barrages, une réduction des débits et par une perturbation de la zonation naturelle. La croissance linéaire du chevaine a été étudiée par scalimétrie, sur six stations du bassin versant de la Durance, dont deux sur ses affluents principaux, le Bueç et le Verdon. Une analyse de variance, sur la taille moyenne des poissons de 1 à 5 ans confirme des différences significatives entre les stations. Une Analyse en Composante Principale, dans laquelle les stations sont caractérisées par 8 variables mésologiques auxquelles on a adjoint la densité des invertébrés et le nombre de degrés- jours au dessus de $12^{\circ}$ et $22^{\circ} \mathrm{C}$, a permis de relier les variations de la taille du chevaine à l'habitat de l'espèce défini en termes de vitesse du courant, de profondeur, de substrat. Cette corrélation croissance - présence de zones plus profondes peut s'expliquer de deux façons : 1- dans les zones de radiers lents, homogènes, l'épaisseur d'eau insuffisante et l'absence de caches limitent la diversité des habitats et la richesse biologique du secteur ; mais l'abondance des invertébrés ne semble pas, un élement déterminant ; 2 - dans les zones de radiers lents soumises à des variations thermiques très grandes et rapides, pendant la journée et les saisons, la température des eaux de cette rivière méditérranéenne peut être très élevée. Les poissons de plus de deux ans, recherchent alors des zones profondes où l'inertie thermique est plus grande. 


\section{Introduction}

The study of growth of fish offers to a system ecologist many opportunities to enquire into the dynamic balance and states of change in aquatic ecosystems $\dagger$ (Weatherley 1972). With fish, growth is very labile, influenced by food, space, temperature and other factors. Furthermore, since fish are both poikilothermic and live permanently in water, they are directly affected by changes in temperature in their ambient medium. For Le Cren (1958) and Mann (1976), water temperature is the essential factor of control of the growth rate of fish, essentially physiological.

More recently, several authors have demonstrated that the environment is of predominant importance in the distribution of Cyprinidae communities (Granado Lorencio et al. 1986, Mc Nelly 1987, Grossman et al. 1987, De Jalon et al. 1988, Copp et al. 1991, Grosmann \& Sostoa 1994, Mastrorillo et al. 1996).

Since the early 1960, the mediterranean river Durance, has undergone a series of hydroelectric developments that have involved in a considerable reduction of the flow rate and created unsurmountable barriers. Moreover, the extraction of alluvial deposits from the substrate has altered the morphology of the river bed and caused a regressive erosion at various places.

It has been suggested that flow regulation below hydroelectric dams has considerable effects on running water communities, such as the disappearance of certain habitats (Mann 1986), or the alteration of temperature patterns and flow fluctuations ( Higg \& Petts 1988). They may have a two fold impact on the fish fauna by changing the physical environment (Camargo \& Garcia de Jalon 1990), and the food supply (Muñoz \& Prat 1989).

How do abiotic and biotic factors interact on the growth of fish in regulated flow water ?

The environmental impact caused by an hydropower reservoir on its downstream ecosystem has been assessed. The two major aims of this study were : 1 - to determine the responses of linear growth of chub to the instream changes produced by this hydroelectric regulation ; 2- to estimate and quantify the main environmental factors such as density of prey invertebrates, temperature, slope, flow rate, depth, responsible for such responses.

\section{Material and methods}

\subsection{Study area}

The Durance River, rises in the Alps at the Mont Genèvre (alt. $2400 \mathrm{~m}$ ) and flows into the Rhône in Avi- gnon (alt. $13 \mathrm{~m}$ ) covering a length of $300 \mathrm{~km}$. Its course has been fragmented by the construction of 9 dams. The Serre Ponçon dam (alt. $780 \mathrm{~m}$ ) marks the boundary between the upper reache of the Durance, exclusively populated by trout Salmo trutta L.) and bullhead (Cottus gobio L.), and the lover reache where cyprinids become dominant. The mean annual flow rate (19401985 ) at the inflow to the Serre Ponçon reservoir is $83 \mathrm{~m}^{3} \mathrm{~s}^{-1}$. At the outlet from the turbines set at the bottom of the dam, most of the water is diverted into a canal parallel to the Durance, and the flow rate of the remaining water is only $2 \mathrm{~m}^{3} \mathrm{~s}^{-1}$. Before the construction of the hydroelectric facilities the mean annual flow rate at its confluence with the Rhône was about 190 $\mathrm{m}^{3} \mathrm{~s}^{-1}$, whereas it is now about $10 \mathrm{~m}^{3} \mathrm{~s}^{-1}$.

Six stations were studied : four of them situated along the Durance (1D Espinasse, 2D Manosque, 3D Pertuis, 4D Sénas) and two along the major tributaries, the Buech (5B Laragne) and the Verdon (6V Vinon) (Fig 1). They consist of a series of riffles, pools and holes of different depth. In most of the stations, the water is shallow and the range of annual temperature variation is wide. The air temperatures 1995 , at hourly intervals, were provided by Météo France for all the six stations, while the water temperatures for the stations $1 \mathrm{D}$ and $2 \mathrm{D}$, were provided at the same intervals, by Electricité de France. On the basis of these two sets of 24 hours x 365 days measurements, we have calculated for each station an air temperature / water temperature linear relation $(r=0.82)$, as well as the annual maximum temperature and the sum of degree-days above $12^{\circ} \mathrm{C}$ and $22^{\circ} \mathrm{C}$, a method already used by Mann (1976) in a former study on the chub.

For each station, we undertook a morphodynamic description covering slope (measured using a Topcon ${ }^{\circledR}$ theodolite - distancemeter), water velocity (measured using a Ott ${ }^{\circledR}$ microvelocimeter), depth of water and nature of the substrate. We characterised four types of morphological units and measured their frequency in each of the sectors studied: shallow riffles, deep riffles, pools and shelters according to Malavoi (1989) (Table 1). Shelters are considered as natural hides available to fish along the banks or in the bed of the river. They take the form of unblocked rock hole cavities beneath the banks or log jams.

\subsection{Sampling methods}

Data on density of invertebrates (ind. / $\mathrm{m}^{-2}$ ) at stations 2D, 3D and 4D have been taken in Prevot (1984). Data on the three other stations were obtained by eight collections with a rom net in morphodynamic conditions characteristic of each station in the three seasons 


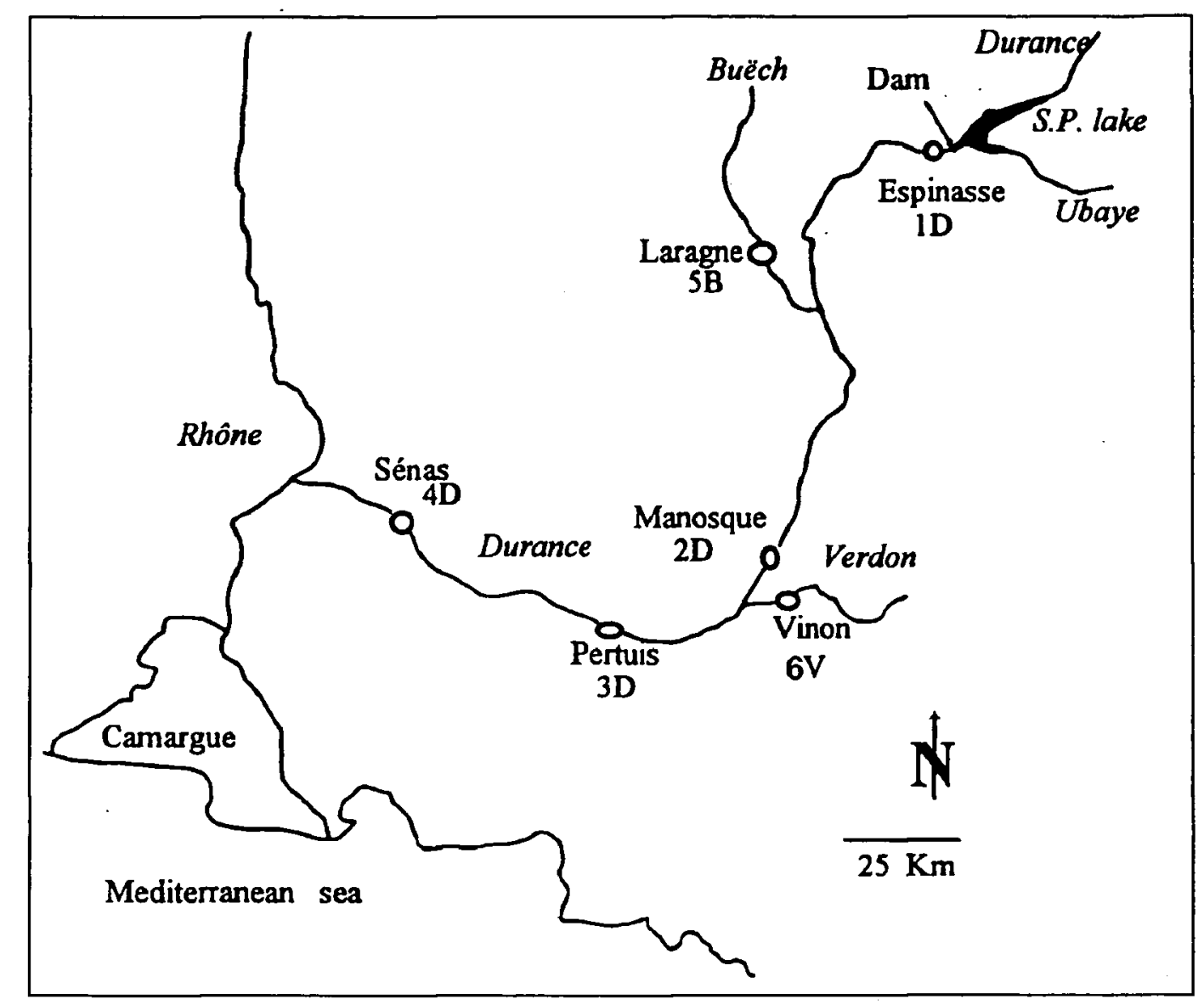

Fig. 1. Map showing the location of the sampling stations (S.P. = Serre Ponçon dam).

Fig. 1. Carte de localisation des stations de prélèvements (S.P. = lac de Serre Ponçon).

Table 1. Main characteristics of facies along the Durance river and its tributaries.

Tableau 1. Caractéristiques des faciès rencontrés sur la Durance et ses affluents.

\begin{tabular}{|c|c|c|c|}
\hline Facies & $\begin{array}{l}\text { Velocity } \\
\left(\mathrm{m} \cdot \mathrm{s}^{-1}\right)\end{array}$ & $\begin{array}{c}\text { Depth } \\
\text { (m) }\end{array}$ & Substrate \\
\hline Riffle 1 & $>0.4$ & $<0.30$ & shingles $(5-10 \mathrm{~cm})$ \\
\hline Riffle 2 & $>0.4$ & $>0.30$ & shingles $(5-10 \mathrm{~cm})$ \\
\hline Pool & $<0.4$ & $>0.50$ & sand, silt \\
\hline Shelters & near zero & $>0.30$ & any substrate \\
\hline
\end{tabular}

spring, summer and autumn. Data on fish communities were obtained in riffle sectors by electrical fishing and by gill nets in deep areas (pools) (Bengen et al. 1992, Hutagalund et al. 1997). Four fish sampling series per station (December 1994, March, June, September 1995) enabled the assessment of the structure of fish communities. The fish density at each station was cal- culated using De Lury's method (Seber \& le Cren 1961), in the zones of riffles and in the river bank of the pools. In the central area of the pools, captures with gill nets were measured as catch unit/effort (Hutagalund et al. 1997). However, only few large fish were caught by this way and therefore, they were not included in the evaluation of population sizes for the stations 1D, 3D, $4 \mathrm{D}$ and 6V. Fork lengths were measured with an accuracy of $0.5 \mathrm{~cm}$ and a sample of scales was taken behind the dorsal fin, outside the lateral line (Vibert \& Lagler 1961), between December 1994 and March 1995 at each station. The determination of age was achieved by scalimetric method (Libovsvarsky 1956, Balon 1962, Penaz 1968, Cragg Hine \& Jones 1969, Hellawell 1971, Philippart 1972, Mann 1976). With the Cyprinidae, it is difficult to estimate accurately the age of fish older than ten years, since erosion on the scales can be extensive and may mask certain annuli (Philippart 1972). Various authors have shown that female chub often have a faster growth rate than males of VI - VII years old (Cragg Hine \& Jones 1969, Hellawell 1971, Mann 1976). During the present study, the specimens were released into the water after taking of scales, and therefore, their sex could not be determined. 


\subsection{Statistical procedures}

The back calculation formula used was that of Le Cren (1947): $\mathrm{Lt}=\mathrm{Li}+a(\mathrm{Rt}-\mathrm{Ri})$ where $\mathrm{Lt}$ et $\mathrm{Rt}$ are the length of the fish and of the radius of the scale at the time (t), $\mathrm{Li}$ et $\mathrm{Ri}$ are the same measurements at the time of catching, and $(a)$ is a constant. The differences between the mean sizes of fish from six samples were tested by analysis of variance (STATITCFC program ANOVA) : only the cohorts represented by at least 20 individuals were considered, which limited the analysis to the first five years of age. The $F$ test of the heterogeneity of the six samples was highly significant. The Newman-Keuls test made it possible to constitute homogeneous clusters. In order to try to explain the differences observed in the various stations for five age classes of chub, we carried out a Principal Component Analysis (STATITCFC program), to distinguish the determinant variables (facies, temperature max., degree-days $\left(>12^{\circ} \mathrm{C}\right.$ and $>22^{\circ} \mathrm{C}$ ), slope, altitude, invertebrate density), of the structure observed. The morphodynamic characteristics of each station and the invertebrate densities (Table 2) were introduced as active variables. The sizes recorded from one to five years constitute 5 additional variables, the «size variables», a coding which was already used in a previous work on the brown trout in Corsica (Chappaz et al. 1996).

\section{Results}

The six studied stations differ by their mesological characteristics. The angle of slope decreases linearly from upstream to downstream, whereas the maximum temperature and the sum of degree-days above 12 and $22^{\circ} \mathrm{C}$ increases (Table 2). On the other hand, the density of benthic invertebrates does not appear to be linked neither to slope nor altitude. In these stations, numerically the chub represents one third of the fish fauna (Table. 3). The other species found include the barbel (Barbus barbus (L.) 1766), the nase (Chondrostoma nasus (L.) 1766), the common trout (Salmo trutta L. 1758), the spirlin (Alburnoides bipunctatus (Bloch) 1785 ) in the lower reaches, and the blageon (Leuciscus (Telestes) souffia Risso 1826) in the upper reaches (Chappaz \& Brun 1993).

The scalimetric analysis of the chub was carried out on 557 individuals. A close linear correlation between the length of the fish and the anterior radius of the scale was found (Table 4). Sizes using back-calculated method are given in the figure 2). The analysis of va-

Table 2. Morphodynamic features of the stations studied along the Durance river, downstream from Serre Ponçon dam, and along its tributaries. (For riffle characteristics, see table $1 .$, Inv. $\mathrm{m}^{-2}$ is the number of benthic invertebrates per square metre).

Tableau 2. Description morphodynamique des stations étudiées sur la Durance à l'àval de la retenue de Serre Ponçon. (Pour.les caractéristiques des radiers, lire le tableau 1. Inv. $\mathrm{m}^{-2}$ est le nombre d'invertébrés benthiques par $\mathrm{m}^{2}$ ).

\begin{tabular}{|c|c|c|c|c|c|c|c|c|c|c|c|c|c|c|}
\hline \multirow[t]{3}{*}{ Stations } & \multirow{3}{*}{$\begin{array}{c}\text { Altitude } \\
\text { (m) }\end{array}$} & \multirow{3}{*}{$\begin{array}{l}\text { Slope } \\
\text { (\%) }\end{array}$} & \multirow{3}{*}{$\begin{array}{c}\text { Area } \\
\text { m }^{2}\end{array}$} & \multicolumn{4}{|c|}{ Facies (\% of the station area) } & \multicolumn{3}{|c|}{ Temperaturd ${ }^{\circ} \mathrm{C}$ ) } & \multicolumn{4}{|c|}{ Invertebrates } \\
\hline & & & & \multirow[t]{2}{*}{ Riffle 1} & \multirow{2}{*}{ Riffle 2} & \multirow[t]{2}{*}{ Pools } & \multirow[t]{2}{*}{ Shethers } & \multirow[t]{2}{*}{$\max$} & \multicolumn{2}{|c|}{ Days Degree } & \multirow[b]{2}{*}{ spring } & \multicolumn{2}{|c|}{$\left(\right.$ ind $\left.m^{-2}\right)$} & \multirow[b]{2}{*}{ Mean } \\
\hline & & & & & & & & & $>12^{\circ} \mathrm{C}$ & $>22^{\circ} \mathrm{C}$ & & summer & auturm & \\
\hline ID & 635 & 0.55 & 1930 & 33 & $\begin{array}{l}0 \\
0\end{array}$ & 34 & 33 & 21,3 & 538 & $\begin{array}{l}0 \\
0\end{array}$ & 4963 & 3585 & 3369 & 3972 \\
\hline 2D & 290 & 0.50 & 2250 & 90 & 0 & 5 & 5 & 27,1 & 988 & 33 & 2420 & 3010 & 5000 & 3477 \\
\hline 3D & 195 & 0.38 & 2350 & 10 & 55 & 20 & 15. & 29 & 1042 & 327 & 4530 & 3720 & 4820 & 4357 \\
\hline 4D & 85 & 0.30 & 2560 & 60 & 15 & 15 & 10 & 30,2 & 1198 & 253 & 1250 & 1585 & 1263 & 1366 \\
\hline 5B & 520 & 0.50 & 2270 & so & 40 & 5 & 5 & 29 & 994 & 307 & 675 & 3413 & 3627 & 2572 \\
\hline 6V & 256 & 0.20 & 1430 & 25 & 25 & 25 & 25 & 25 & 970 & 25 & 4520 & 3760 & 5120 & 4467 \\
\hline
\end{tabular}

Table 3. Density of Leuciscus cephalus in six stations along the Durance River in 1995.

Tableau 3. Densité du chevaine Leuciscus cephalus, sur les six stations étudiées en 1995.

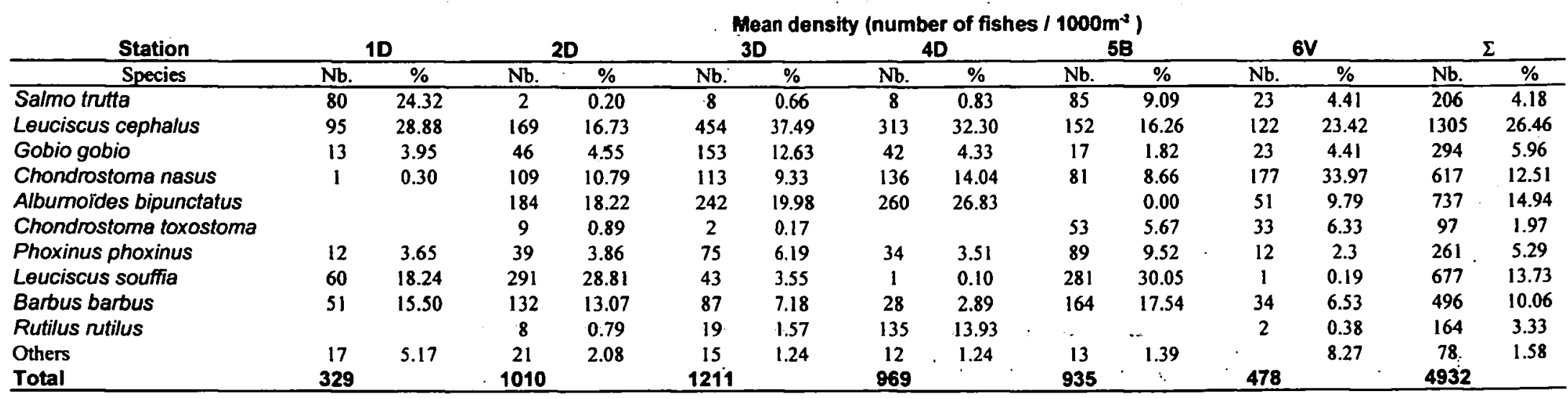


Table 4. Parameters of the relationship between the fork length (Lf) and the anterior radius $R$ of scale, in chub from the Durance river : $\mathrm{Lf}=\mathrm{aR}+\mathrm{b}: \mathrm{r}$ is the coefficient of linear correlation $; \mathrm{a}$ and $\mathrm{b}$ are the parameters.

Tableau 4. Paramètres de la relation entre la longueur à la fourche (Lf) et le rayon antérieur $\mathrm{R}$ de l'écaille, chez les chevaines de la Durance. $\mathrm{Lf}=\mathrm{aR}+\mathrm{b}: \mathrm{r}$ est le coefficient de corrélation ; $\mathrm{a}$ et $\mathrm{b}$ sont deux paramètres.

\begin{tabular}{cccc} 
Station & $\mathrm{a}$ & $\mathrm{b}$ & $\mathrm{r}$ \\
\hline 1D & 5.08 & 0.234 & 0.977 \\
2D & 4.944 & 5.029 & 0.984 \\
3D & 4.993 & 4.488 & 0.98 \\
4D & 4.663 & 4.977 & 0.983 \\
5B & 5.556 & 3.99 & 0.979 \\
6V & 4.938 & 0.944 & 0.959 \\
\hline
\end{tabular}

riance shows that the growth rate differs among the stations (Table 5). During the first year, the growth rate was faster at the stations D2, D3 and D4 in the middle and lower reaches of the Durance. This tendency gradually decreased from one to two years, then from three to four years, where no more than three distinct groups could be discerned. At the age of five years, a certain uniformity of the mean size of the chub was apparent. Except during the first year, the slowest growth rate was always recorded in station D2.

The first three axes explain respectively $50.5 \%$, $25.8 \%$ and $15.2 \%$, or altogether $91,5 \%$ of the variance (Table 6). The first axis is essentially correlated with maximum temperature $(-0.98)$, the number of degree-days above $12^{\circ} \mathrm{C}(-0.93)$, and the frequency of shelters and pools $(0.89,0.80)$. The second axis is correlated with the frequency of riffle facies $(0.89$ for the shallow riffles and -0.72 for the deep riffles), and the third axis with the altitude and the slope. The «size variables» are poorly correlated with the axis 3 and the proportion of their variation explained by this axis is negligible. On the contrary, the axes 1-2 explain much of the size variation, between $42 \%$ to $90 \%$ according to the age. This means that in the Durance river, the growth rate of the chub is largely influenced by the local morphodynamic conditions. At the age of one year, body size is mainly influenced by water temperature: its correlation with the two axes is negative $(-0.75$, 0.13 ). In individuals older than one year, the «size variables» are linked with the axis 2 , by a negative correlation and with the axis 1 by a lower positive correlation. This means that for fish older than two years, the

Table 5. Growth of chub in different stations along the Durance. Lf is the fork length (in cm).

Tableau 5. Croissance du chevaine dans différentes stations de la Durance. Lf est la longueur à la fourche (en cm).

\begin{tabular}{cccccccccccc}
\hline \multirow{2}{*}{ Stations/Ages } & I & II & III & IV & V & VI & VII & VIII & IX & X \\
\hline 1D & Lf & 5.0 & 9.4 & 13.4 & 16.8 & 19.9 & 22.8 & 25.0 & 27.0 & 28.7 & 29.4 \\
& $s_{L f}$ & 1.0 & 1.8 & 2.0 & 2.0 & 2.2 & 2.4 & 2.7 & 2.9 & 2.7 & 3.5 \\
& $\mathrm{n}$ & 80 & 67 & 61 & 55 & 49 & 44 & 30 & 23 & 8 & 3 \\
2D & Lf & 6.6 & 8.3 & 10.2 & 12.5 & 15.1 & 17.6 & 20.5 & 23.6 & 27.9 & 33.1 \\
& $s_{L f}$ & 0.4 & 0.6 & 0.7 & 0.8 & 1.2 & 1.0 & 0.9 & 0.8 & 1.6 & 0.8 \\
& $\mathrm{n}$ & 83 & 71 & 57 & 47 & 43 & 34 & 28 & 23 & 14 & 7 \\
3D & Lf & 7.3 & 9.7 & 12.6 & 15.3 & 19.8 & 22.4 & 24.7 & 27.6 & 31.7 & 33.4 \\
& $s_{L f}$ & 0.9 & 1.0 & 1.5 & 2.1 & 1.8 & 1.6 & 1.6 & 2.1 & 0.4 & 0.1 \\
& $\mathrm{n}$ & 138 & 90 & 81 & 62 & 20 & 14 & 10 & 5 & 3 & 2 \\
4D & Lf & 6.6 & 8.7 & 12.6 & 16.7 & 20.8 & 26.1 & 30.9 & 34.9 & 37.1 & 40.5 \\
& $s_{L f}$ & 0.4 & 0.8 & 1.3 & 1.6 & 2.1 & 2.0 & 1.8 & 1.7 & 1.9 & 2.8 \\
& $\mathrm{n}$ & 74 & 63 & 59 & 58 & 49 & 30 & 24 & 14 & 8 & 5 \\
5B & Lf & 6.0 & 8.9 & 12.4 & 15.5 & 19.1 & 22.0 & 26.9 & 30.1 & 33.5 & \\
& $s_{L f}$ & 0.4 & 0.7 & 1.3 & 1.5 & 1.6 & 2.0 & 1.9 & 2.0 & 0.9 & \\
& $\mathrm{n}$ & 94 & 83 & 77 & 50 & 23 & 15 & 5 & 3 & 2 & \\
6V & Lf & 5.0 & 10.0 & 14.8 & 19.1 & 22.0 & 24.9 & 27.6 & 31.2 & 35.2 & 38.9 \\
& $s_{L f}$ & 0.6 & 1.4 & 1.3 & 1.7 & 2.6 & 3.2 & 3.2 & 3.6 & 4.0 & 0.2 \\
& $\mathrm{n}$ & 88 & 75 & 62 & 53 & 43 & 24 & 13 & 10 & 5 & 2 \\
\hline
\end{tabular}


Table 6. Mean length of chub, from one to five years old, in six stations along the Durance river. Newman-Keuls' test (*) after ANOVA shows significantly different homogeneous clusters.

Tableau 6. Taille moyenne retrocalculées des chevaines entre 1 et 5 ans sur les six stations de la Durance; le test de Newman-Keuls $(*)$ après analyse de variance montre des groupes de croissance homogène.

\begin{tabular}{|c|c|c|}
\hline Stations & means & H.C \\
\hline D3 & 7.3 & * \\
\hline D2 & 6.6 & * \\
\hline D4 & 6.6 & * \\
\hline B5 & 5.9 & * \\
\hline V6 & 5.3 & $*$ \\
\hline D1 & 5.0 & * \\
\hline
\end{tabular}

\begin{tabular}{|c|c|c|}
\hline Stations & means & H.C \\
\hline V6 & 9.7 & * \\
\hline D3 & 9.6 & ** \\
\hline D1 & 9.3 & $* *$ \\
\hline B5 & 9.1 & ** \\
\hline D4 & 8.7 & ** \\
\hline D2 & 8.3 & $*$ \\
\hline
\end{tabular}

\begin{tabular}{|c|c|c|}
\hline Age III & & \\
\hline Stations & means & H.C \\
\hline V6 & 13.5 & * \\
\hline D1 & 13.3 & * \\
\hline D4 & 12.6 & * \\
\hline D3 & 12.5 & * \\
\hline B5 & 12.4 & $*$ \\
\hline D2 & 10.1 & * \\
\hline
\end{tabular}

\begin{tabular}{|c|c|c|}
\hline \multicolumn{3}{|l|}{ Age IV } \\
\hline Stations & means & H.C \\
\hline V6 & 17.0 & * \\
\hline D1 & 16.7 & $*$ \\
\hline D4 & 16.9 & $*$ \\
\hline B5 & 15.4 & * \\
\hline D3 & 15.4 & $*$ \\
\hline D2 & 12.5 & * \\
\hline
\end{tabular}

\begin{tabular}{ccc} 
Age V & & \\
\hline Stations & means & H.C \\
\hline D4 & 20.5 & $*$ \\
V6 & 20.0 & $*$ \\
D3 & 19.8 & $*$ \\
D1 & 19.2 & $*$ \\
B5 & 19.2 & $*$ \\
D2 & 15.3 & $*$ \\
\hline
\end{tabular}

factors influencing growth are the presence of pools and holes rather than the water temperature. The most favourable conditions are related to the presence of deep calm facies. The altitude and the density of invertebrates which constitute an important part of the chub's food resource during the first years of life appear to be factors of secondary significance.

\section{Discussion}

The analysis of variance shows significant differences in the growth rate in length for the various sectors of the Durance river. The highest growth rate is found in stations 4D and 6V. In stations $1 \mathrm{D}$ and 3D, growth is very similar, at least up to eight years, and may be compared with those on the English river Lugg (Hellawell 1971). At station 2D, the values are lower and similar to those reported by Libowarsky (1956) for the Suratka (Czechoslovakia), a river that has been disturbed by the construction of a hydroelectric dam and by Philippart (1972) for the Belgian Berwine, a severely polluted river.

The statistical procedures confirm that the shallow riffle sectors, with low diversity, appear to be unfavourable to a rapid growth beyond one year of age. The growth rate is related to the structure of the environment and, in particular, to the occurrence of areas of deep water with low current speed. Furthermore, with cyprinids, the increase in body size is often associated with a change in preferred habitat, such as with the nase (Nelva 1988) and the barbel (Philippart 1977), which both prefer deep water when adult.

There is a normal range of temperatures between $0^{\circ}$ and $30^{\circ} \mathrm{C}$, to which fishes are adapted. However, their tolerance to high temperatures, is varying with species, their stage of development, their acclimatation temperature, the dissolved oxygen and the season. The knowledge of the upper limits of temperature and optimal temperature for growth of fish is abundant; even though few studies concern the chub directly. The value of selected temperature for chub growth is between $8^{\circ}$ and $25^{\circ} \mathrm{C}$ and the «disturbing» temperature is > $30^{\circ} \mathrm{C}$ (Horoszewicz 1973, Elliott 1981). However, chub are adapted to such seasonal changes of temperature and they may also be capable of withstanding changes outside this range, especially those of short term duration, though at the same time they may succumb to unnatural fluctuations within this range. But, the deepest areas in pools and holes, possess a higher degree of thermic inertia and constitute sortes of «thermic refuges» while the temperature of the riffles, characteristic of very shallow water layers, may be more unsteady. In addition, pools and holes provide shelters, where energy consumption associated with movement or static swimming is at a minimum. 
Table 7. Principal Component Analysis on a table (stations $x$ variables). The variables of table 2 are active variables. Length (Lf) from one to five years are additional variables. ( $r$ ) is the correlation between the variables and the three principal axis. $\mathrm{R}^{2}$ measures the proportion of the variation of a variable explained by the axis.

Tableau 7. Analyse en composantes principales (stations $\mathrm{x}$ variables). Les variables du tableau 2 sont des variables actives. Les longueurs (Lf) de 1 à 5 ans sont des variables additionnelles. ( $r$ ) est le coefficient de corrélation entre les variables et les trois axes principaux. $R^{2}$ mesure la part de variation d'une variable expliquée par l'axe.

\begin{tabular}{|c|c|c|c|c|c|c|}
\hline \multirow{2}{*}{$\begin{array}{l}\text { eigenvalues } \\
\% \text { variation }\end{array}$} & \multicolumn{4}{|c|}{$F 1=5.05 \quad F 2=2.58 \quad F 3=1.51$} & & \\
\hline & & 50.5 & 25.9 & 15.2 & & \\
\hline & \multicolumn{3}{|c|}{$\mathrm{r}$ (variables/axis) } & \multicolumn{3}{|c|}{$\mathrm{R}^{2}$ (variables/axis) } \\
\hline & F1 & $\mathrm{F} 2$ & F3 & $\mathrm{F} 1$ & F2 & F3 \\
\hline Altitude & 0.64 & 0.36 & 0.60 & 0.41 & 0.13 & 0.37 \\
\hline Slope & 0.25 & 0.66 & 0.66 & 0.06 & 0.44 & 0.43 \\
\hline Riffle 1 & -0.34 & 0.89 & -0.27 & 0.12 & 0.80 & 0.07 \\
\hline Riffle 2 & -0.44 & -0.73 & 0.50 & 0.20 & 0.53 & 0.25 \\
\hline Pools & 0.81 & -0.46 & -0.15 & 0.65 & 0.21 & 0.02 \\
\hline Shelters & 0.90 & -0.36 & -0.14 & 0.81 & 0.13 & 0.02 \\
\hline $\mathrm{Tm}$ & -0.99 & -0.09 & 0.14 & 0.97 & 0.01 & 0.02 \\
\hline d.d $>12^{\circ} \mathrm{C}$ & -0.94 & -0.20 & -0.29 & 0.87 & 0.04 & 0.08 \\
\hline d.d $>22^{\circ} \mathrm{C}$ & -0.75 & -0.35 & 0.50 & 0.56 & 0.12 & 0.25 \\
\hline Im & 0.63 & -0.41 & 0.09 & 0.40 & 0.17 & 0.01 \\
\hline $\mathrm{L}_{\mathrm{f}} 1$ year & -0.75 & -0.13 & 0.08 & 0.56 & 0.02 & 0.01 \\
\hline $\mathrm{L}_{\mathrm{f}} 2$ years & 0.42 & -0.85 & 0.21 & 0.18 & 0.72 & 0.05 \\
\hline $\mathrm{L}_{\mathrm{f}} 3$ years & 0.41 & -0.66 & $0.03^{-}$ & 0.17 & 0.43 & 0.01 \\
\hline $\mathrm{L}_{\mathrm{f}} 4$ years & 0.13 & -0.63 & -0.19 & 0.02 . & 0.40 & 0.04 \\
\hline$L_{f} 5$ years & 0.44 & -0.75 & -0.08 & 0.19 : & 0.57 & 0.01 \\
\hline
\end{tabular}

In the Durance, higher temperatures favorize the predominance of Cyprinids and the elevated growth rate of the chub during his first year of life : the number of degree-days $>12^{\circ} \mathrm{C}$, between 538 (1D) and 1198 (4D), is well above those calculated for the river Stour (Mann 1976) or the Lake Windermere (Le Cren 1958). But the higher temperature plays a secondary role in influencing the growth rate of the chub older than two years, as the optimum values for the chub are reached everywhere and the temperature parameter does not allow us to make a distinction between the stations.

For Mc Neely (1987) and De Jalon et al. (1988), the trophic dimension of the niche determines the pattern of distribution of the Cyprinidae populations. The present study shows that in the Durance, this factor is secondary, since it is above all the physical dimension of the habitat that have an effect upon the distribution pattern and growth rate of the chub.
In natural water courses, the frequency of calm deep habitats increases progressively downstream. However, in the Durance river, the frequency of these habitats and the growth rate of the chub are no longer directly related to the upstream-downstream gradient because of the perturbations caused by the reduction of the flow rate; the presence of dams and the extraction of alluvial deposits in the secondary river bed have jumbled up any formerly present gradient.

\section{References}

Balon K.E. 1962. - Age and growth of the chub Leuciscus cephalus in the Orava River (1944-1952) and in Orava Riverine Lake in the years following its filling (1953-1958). Prace laboratoria $R y$ barstua, 1 : 79-104.

Bengen D., Belaud A. \& Lim P. 1992. - Structure et typologie ichtyenne de trois bras morts de la Garonne. Annls. Limnol., 28 : 3556. 
Camargo J.A. \& Garcia de Jalon D. 1990. - The downstream impacts of the Burgomillodo reservoir, Spain. Regulated Rivers, 5 : 305- 317.

Casado C., Garcia de Jalon D.G., Del Olmo C., Barcelo E. \& Menes F. 1989. - The effects of an irrigation and hydroelectric reservoir on its downstream communities. Regulated Rivers, 4 : 275-284.

Chappaz R. \& Brun G. 1993. - Données nouvelles sur la biologie et l'écologie d'un poisson cyprinidé du sud de l'Europe Leuciscus (Telestes) soufia (Risso, 1826). C. R. Acad. Sci. Paris, t. 316, série III : 35-41.

Chappaz R., Olivari G. \& Brun G. 1996. - Food availability and growth rate in natural populations of the brown trout (Salmo trutta) in Corsica streams. Hydrobiologia, $331: 63-69$.

Copp G.H., Olivier J.M., Penaz M., Roux A.L. 1991. - Juvenils fishes as functional describers of fluvial ecosystem dynamics: applications on the River Rhône. Regulated Rivers, 6 : 135-145.

Cragg Hine D. \& Jones J.W. 1969. - The growth of Dace, Leuciscus leuciscus, Roach Rutilus rutilus and Chub Squalius cephalus

1 in Willow Brook. J. Fish. Biol. 1 : 59- 82.

Elliott J.M. 1981. - Some aspect of thermal stress on Freshwater Teleosts. in Stress and Fish, A.D. Pickering (ed.) Acad. Press, London : 209-245.

Garcia de Jalon D.G., Montes C., Barcelo F., Casado C.\& Menez F. 1988. - Effects of hydroelectric scheme on fluvial ecosystems within the spanish pyrenees. Regulated Rivers, $2: 479-491$.

Granado Lorencio C. \& Garcia Novo F. 1986. - Feeding habits of the fish community in an eutrophic reservoir in Spain. Ekologia Polska. 34 : 95-110.

Grossman G.D., De Sostoa A., Freemann M.C. \& Lobon Cervia J. 1987. - Microhabitat use in a mediterranean riverine fish assemblage. Oecologia, 73 : 501-512.

Grossman G.D. \& De Sostoa A. 1994. - Microhabitat use by fish in the upper Rio Matarrana, Spain 1984-1987. Ecol. Freshwat. Fish., $3: 141-152$.

Hellawell J.M. 1971. - The autecology of the chub Squalius cephalus L. of the river Lugg and Afon Llynfi. I - Age determination structure. Freshwater Biol., : 29-60.

Higgs G. \& Petts J. 1988. - Hydrological changes and river regulation in the UK. Regulated Rivers, $2: 349-368$.

Horoszewicz L.1973. - Lethal and disturbing temperature in some fish species from lakes with normal and artificially elevated temperature. J. Fish. Biol., $5: 165-181$.

Hutagalung R.A, Lim P., Belaud A. \& Lagarrigue T. 1997. — Effets globaux d'une agglomeration sur la typologie ichtyenne d'un fleuve : cas de la Garonne à Toulouse. Annls. Limnol., 33 (4) : 263-280.

Le Cren E.D. 1947. - The determination of the age and growth of the perch Perca fluviatilis from the opercular bones. J. Anim. Ecol., 16 : 188-204.
Le Cren E.D. 1958. - Observation of the growth of the perch over twenty two years with special reference to the effects of temperature and changes in population density. J. Anim. Ecol., $27: 187$ 334.

Libosvarsky J. 1956. - Rust jelce tlouste Leuciscus cephalus a revise dvou hlarnich method jeho zpetnho stanoveni. Zool. Listy, 5 (19) : 302-31 .

Malavoi J.R. 1989. - Typologie des faciés d'écoulement ou unités morphodynamiques des cours d'eau à haute énergie. Bull. Fr. Pêche Piscic., 315 : 189-210.

Mann R.H.K. 1976. - Observations on the age, growth, reproduction and food of the chub Squalius cephalus (L.) in the River Stour, Dorset. J. Fish. Biol., 8 : 265-288.

Mann R.H.K. 1988. - Fish and fisheries of regulated rivers in the UK. Regulated Rivers, 2 : 411-424.

Mastrorillo S., Dauba F. \& Belaud A. 1996. - Utilisation des microhabitats par le vairon, le goujon et la loche franche dans trois rivières du sud ouest de la France. Annls. Limnol., 32 (3) : 185196.

Muñoz I. \& Prat N. 1989. - Effects of river regulation on the lower Ebro river, Spain. Regulated Rivers, $3:$ 345-354.

Nelva A. 1988.. - Profil écologique du Hotu, Chondrostoma nasus (Ostéichtyen, Cyprinidé) dans le Haut-Rhône français : structure d'habitat ponctuel et stationnel. Acta Oecol. Oecol. Applic., 9 (3) : 275-296.

Mc Neely D.L. 1987. — Niche relations within an Ozark stream cyprinid assemblage. Environ. Biol. Fish.,, 18 : 195-208.

Penaz M. 1968. — Laboratorni pristoj pro lihnvti rybich s cirkulujoci vodov. Verte brat. Zpravy, 2 : 15- 30.

Philippart J.C. 1972. - Age et croissance du chevaine Leuciscus cephalus (L.) dans l'Ourthe et la Berwine. Ann. Soc. Roy. Zool. Belge, $102:$ 47-82.

Philippart J.C. 1977. - Contribution à l'hydrobiologie de l'Ourthe. Dynamique des populations et production de quatre espèces de poissons Cyprinidae : Barbus barbus (L.), Leuciscus cephalus (L.), Chondrostoma nasus (L.) et Leuciscus leuciscus (L.). Thèse de Doctorat, Université de Liège : $225 \mathrm{p}$.

Prevot R. 1984. - Hydrobiologie de la moyenne Durance. Etude des différents milieux et de leurs peuplements de macroinvertébrés. Thèse de Doctorat, Université Aix-Marseille III : $179 \mathrm{p}$.

Seber G.A. \& Le Cren E.D. 1967. — Estimating population parameters from catches large relative to the population. J. Anim. Ecol., $36: 631-643$.

Vibert R. \& Lagler K.F. 1961. - Pêches continentales, biologie et aménagement. Dunod (éd.) Paris : $720 \mathrm{p}$.

Weatherley A.H. 1972. - Growth and ecology of fish populations. Acad. Press., London, : 293 p. 